\title{
Whipple Disease: An Atypical Diagnosis by Capsule Endoscopy in an Oldest-Old Patient
}

\author{
Cláudia Macedo ${ }^{a} \quad$ Elisa Gravito-Soares ${ }^{a, b} \quad$ Marta Gravito-Soares ${ }^{a, b}$ \\ Sandra Lopes $^{\mathrm{a}}$ Rui Caetano-Oliveira ${ }^{c}$ Pedro Figueiredo ${ }^{\mathrm{a}} \mathrm{b}$ \\ ${ }^{a}$ Gastroenterology Department, Centro Hospitalar e Universitário de Coimbra, Coimbra, Portugal; baculty of \\ Medicine, University of Coimbra, Coimbra, Portugal; ${ }^{c}$ Pathology Department, Centro Hospitalar e Universitário de \\ Coimbra, Coimbra, Portugal
}

Keywords

Whipple disease · Capsule endoscopy · Oldest-old

\section{Doença de Whipple: Um diagnóstico atípico por cápsula endoscópica num grande idoso}

\section{Palavras chave}

Doença de Whipple · Endoscopia por cápsula · Grande idoso

An 83-year-old man with arterial hypertension and benign prostatic hyperplasia was referred for chronic intermittent watery diarrhea, colicky abdominal pain, asthenia, anorexia, and weight loss (15-20 kg, a $33 \%$ loss of body weight) with a year of evolution. He denied fever, skin changes, and arthralgia. The patient became dependent on others for daily routine activities. Periods of confusion and disorientation were also reported. On physical examination, evidence of severe cachexia (body mass index $15.7 \mathrm{~kg} / \mathrm{m}^{2}$ ), a painless abdomen

karger@karger.com www.karger.com/pjg

Karger $\stackrel{\text { ' }}{5}$

GOPEN ACCESS
(C) 2021 Sociedade Portuguesa de Gastrenterologia. Published by S. Karger AG, Basel

This is an Open Access article licensed under the Creative Commons Attribution-NonCommercial-4.0 International License (CC BY-NC) (http://www.karger.com/Services/OpenAccessLicense), applicable to the online version of the article only. Usage and distribution for commercial purposes requires written permission. without ascites, and no palpable lymphadenopathy were observed. Upper gastrointestinal endoscopy showed duodenal diffuse whitish stippling, whose histopathological examination reported lymphangiectasias. Ileocolonoscopy with biopsies was unremarkable. Laboratory examinations revealed increased erythrocyte sedimentation rate $(65 \mathrm{~mm} / \mathrm{h}$; normal: $1-20$ $\mathrm{mm} / \mathrm{h})$, increased C-reactive protein $(9.4 \mathrm{mg} / \mathrm{dL}$; normal: $<0.5 \mathrm{mg} / \mathrm{dL})$, mild lymphopenia $\left(0.9 \times 10^{9} / \mathrm{L}\right.$; normal: $1-3 \times 10^{9} / \mathrm{L}$ ), hypochromic microcytic anemia (hemoglobin $7.8 \mathrm{~g} / \mathrm{L}$; normal: $13-17.5 \mathrm{~g} / \mathrm{L}$, mean corpuscular volume $69.9 \mathrm{fL}$; normal: 83-101 fL), elevated prothrombin time (15.5 s; control: $11.4 \mathrm{~s}$ ), hyponatremia (130 mmol/L; normal: $136-146 \mathrm{mmol} / \mathrm{L})$, and hypoalbuminemia (1.9 g/dL; normal: $3.5-5.2 \mathrm{~g} / \mathrm{dL})$. Stools examination for bacteria and parasites were negative. Fecal calprotectin was superior to $6,000 \mathrm{mg} / \mathrm{kg}$ (normal: $<50 \mathrm{mg} / \mathrm{kg}$ ). Interferon gamma release assay, human immunodeficiency virus, and chromogranin A were negative, and thyroid function was normal. Abdominopelvic computed tomography scan identified infracentimetric hypodense ileocolic lymph nodes. On suspicion of a protein-losing enteropathy, a Pillcam ${ }^{\circledR} \mathrm{SB} 3$ 

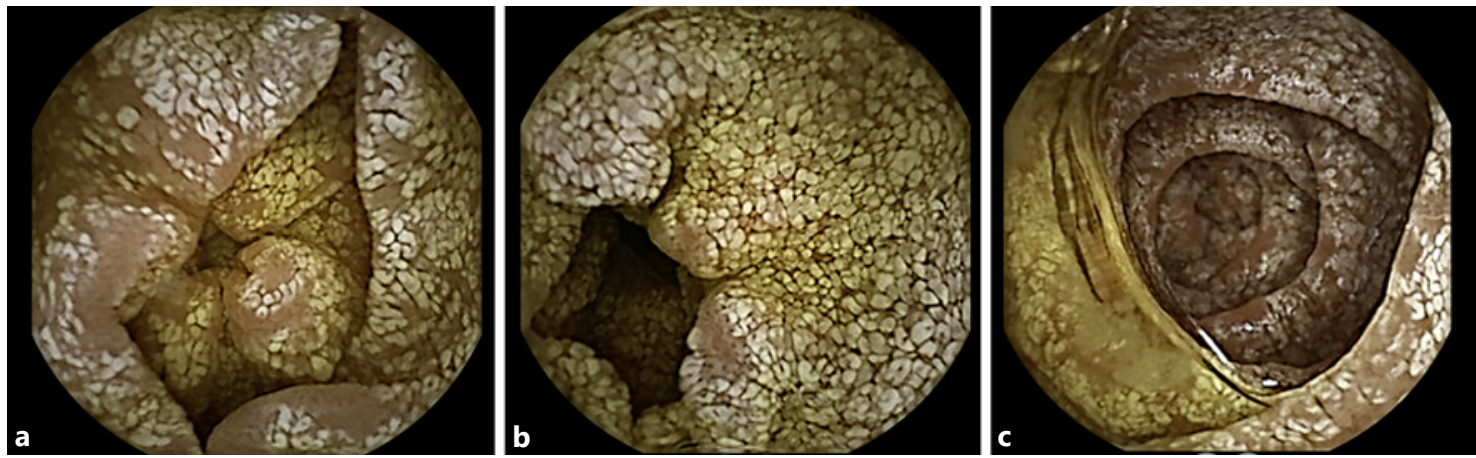

Fig. 1. a-c Capsule endoscopy showing the entire mucosa of the small bowel diffusely edematous with prominent whitish spots.

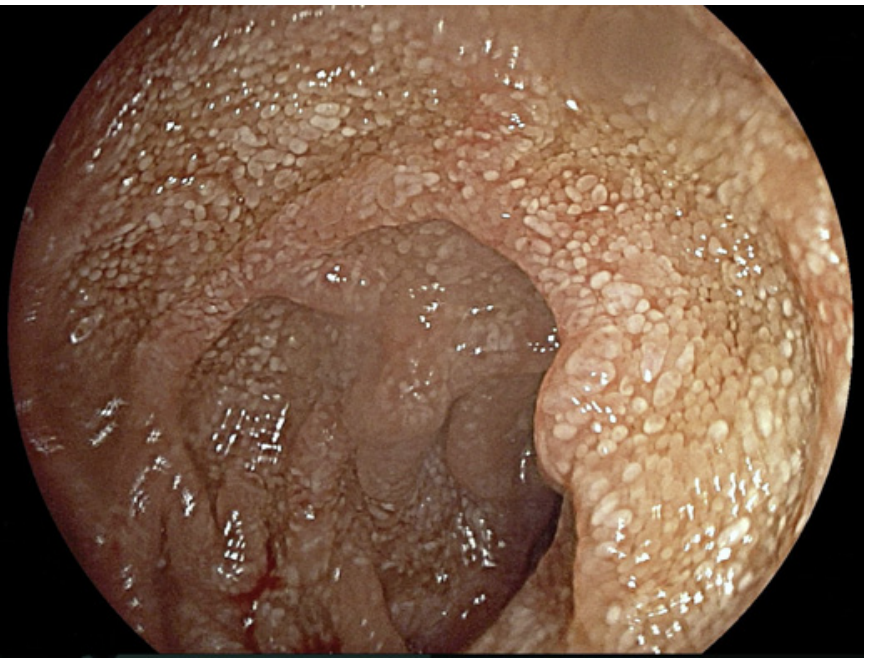

Fig. 2. Upper gastrointestinal endoscopy revealing whitish small plaques diffusely distributed in the intestinal mucosa of the second portion of the duodenum.

capsule endoscopy (Given Imaging Ltd., Yoqneam, Israel) was performed revealing the entire mucosa of the small bowel diffusely edematous with prominent whitish spots (Fig. 1a-c). These endoscopic features led to the suspicion of Whipple disease. To confirm the diagnosis, the patient underwent upper gastrointestinal endoscopy in our institution with duodenal biopsies (Fig. 2). Histopathological examination revealed ectatic lymph vessels in lamina propria and multiple periodic acid-Schiff positive macrophages (Fig. 3a, b). Polymerase chain reaction testing for Tropheryma whipplei DNA was positive. The patient was admitted and started antibiotic treatment with ceftriaxone $2 \mathrm{~g}$ intravenous once daily for 2 weeks followed by trimethoprim-sulfa- methoxazole 160/800 mg twice daily for 1 year. Additionally, parenteral nutrition, personalized diet, and physical rehabilitation were given on a multidisciplinary basis involving nutritionist and physiatrist. Response to treatment was dramatic with diarrhea resolving within several days, significant weight gain in few months and progressive regain of autonomy for daily activities. Reassessment laboratory examinations at 6 and 10 months revealed a normalization of hemoglobin $(14 \mathrm{~g} / \mathrm{dL})$, serum sodium, albumin $(4 \mathrm{~g} / \mathrm{dL})$, and C-reactive protein $(0.5 \mathrm{mg} / \mathrm{dL})$ levels.

Whipple's disease is a chronic and rare multisystemic infection caused by the Gram-positive bacillus Tropheryma whipplei, affecting predominantly white middle-aged males [1]. Upper gastrointestinal endoscopy with biopsies of the small bowel is the diagnostic test of choice, but in some cases, may not establish the diagnosis. In this subset of patients, the capsule endoscopy can have a decisive diagnostic role, especially in a high suspicion of a diffuse but patchy enteropathy, even with nondiagnostic upper gastrointestinal endoscopy with biopsies and abdominal imaging. There are a few cases in the literature describing the almost pathognomonic capsule endoscopic finding of diffuse whitish stippling with or without villous atrophy, erosions, lymphatic ectasia, areas of denuded mucosa [2-5]. We presented an atypical case of Whipple disease not only for the patient's age but also for the endoscopic modality that was decisive in establishing the diagnosis.

\section{Statement of Ethics}

Written informed consent was given by the patient that authorized publication of the case, including images.
Macedo et al. 

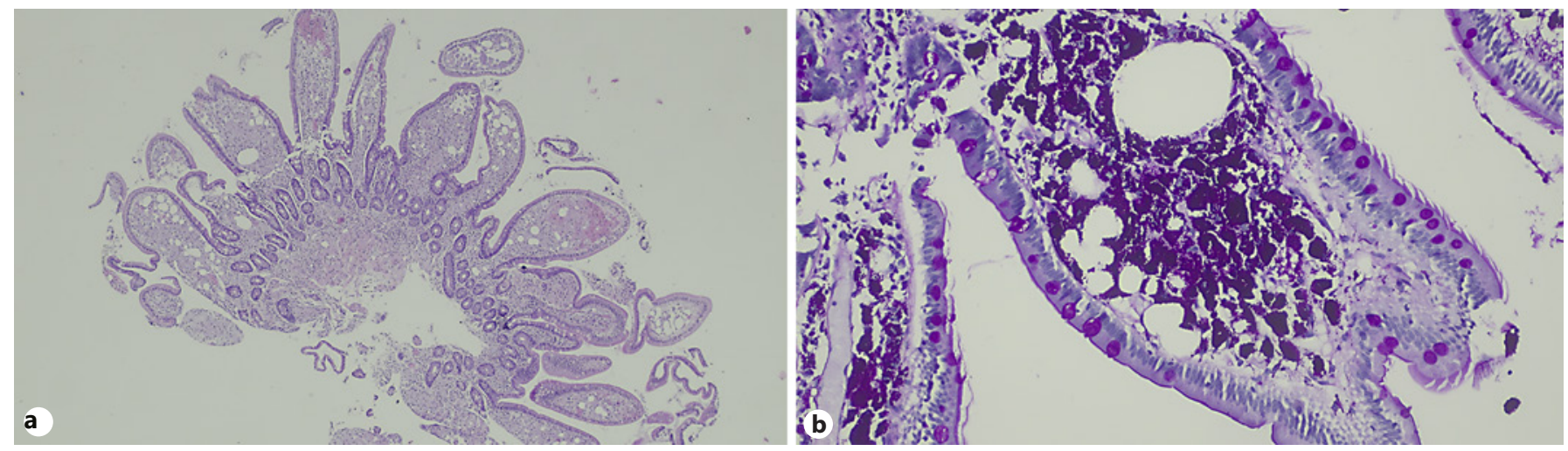

Fig. 3. a, b Histopathological examination of duodenal biopsies by upper gastrointestinal endoscopy showed ectatic lymph vessels in lamina propria and multiple periodic acid-Schiff-positive macrophages.

\section{Conflict of Interest Statement}

The authors declare no conflicts of interest.

\section{Funding Sources}

None.

\section{Author Contributions}

Cláudia Macedo was responsible for the data acquisition and editing, manuscript writing and reviewed the literature. Elisa Gravito-Soares and Marta Gravito-Soares were responsible for the data acquisition and critical revision of the manuscript. Rui Caetano-Oliveira provided the histopathological images and reviewed the histopathological findings. Sandra Lopes and Pedro Narra Figueiredo reviewed the manuscript. All authors approved the published version of the manuscript and agreed to be accountable for all aspects of the work ensuring questions related to the accuracy or integrity of any part of the work were appropriately evaluated and resolved.
References

Whipple Disease Diagnosed by Capsule Endoscopy
1 Dobbins WO 3rd. Whipple's disease. Springfield (Ill.): Charles C. Thomas; 1987.

2 Keane MG, Shariff M, Stocks J, Trembling P, Cohen PP, Smith G. Imaging of the small bowel by capsule endoscopy in Whipple's disease. Endoscopy. 2009;41(S 02 Suppl 2):E139.

3 Mateescu BR, Bengus A, Marinescu M, Staniceanu F, Micu G, Negreanu L. First Pillcam Colon 2 capsule images of Whipple's disease: case report and review of the literature. World J Gastrointest Endosc. 2012 Dec;4(12):575-8.
4 Fritscher-Ravens A, Swain CP, von Herbay A Refractory Whipple's disease with anaemia: first lessons from capsule endoscopy. Endoscopy. 2004 Jul;36(7):659-62

5 Martínez-Sánchez A, Sánche- Ceballos FL, Fernández-Díez S, Suárez-Solís ML, Asteinza-Daganzo M, Baki W, et al. Atypical diagnosis diagnosis by endoscopic capsule: whipple's disease. Rev Esp Enferm Dig. 2016 Mar;108(3):158-62. 